TERMINUS

Vol. 20 (2018), Special Issue, pp. 81-112

doi: $10.4467 / 20843844$ TE. 18.013 .9896

www.ejournals.eu/Terminus

(1D) http://orcid.org/0000-0003-4472-8151

Jakub Niedźwiedź

Jagiellonian University, Cracow

jakub.niedzwiedz@uj.edu.pl

\title{
The Poetical Map of Europe: Jan Kochanowski's Ode II 24 and Its Cartographical Dimensions ${ }^{*}$
}

\begin{abstract}
The paper deals with the problem of cartographic imagination in Polish Renaissance literature. The other problem discussed is the impact of cartographic reason on establishing the early-modern national and European identity of the Poles. The methodological approach of the paper is inspired mainly by critical cartography (J. B. Harley). The term 'map' is defined here in its relatively broad meaning. It is not limited only to material representations, but it is also understood as a performance, a gesture and a form of thinking (D. Woodward, J. Pickles). The main text examined here is Ode II 24 by the Polish Renaissance poet Jan Kochanowski (1530-1584). The poem concludes his lyrical cycle published posthumously in 1585 and it is a Polish imitation of Ode II 20 by Horace (Non usitata nec tenui ferar). In the first part of the paper the author describes the context of the $16^{\text {th }}$-century use of maps. The cartographic revolution of that time had a great impact on art, literature and philosophy etc. Renaissance humanists all over Europe lived within the maps and used them

* This work was supported by the National Science Centre (Poland) under the Grant The Relationship Between Polish Literature and Cartography in the 16th and the First Half of the 17th Centuries (Zwiazzki literatury polskiej i kartografii $w$ XVI $i$ I pot. XVII w.) UMO-2014/15/B/HS2/01104 (K/PBO/000337), DEC-2014/2015/B/ HS2/01104. Polish text: "Humanistyczna mapa Europy Jana Kochanowskiego (Pieśń 24 Ksiag wtórych)," in: Literatura renesansowa w Polsce i Europie. Studia dedykowane Profesorowi Andrzejowi Borowskiemu, red. J. Niedźwiedź, Kraków 2016, pp. 251-273.
\end{abstract}


as a tool or as a means of expressing, defining and shaping their ideas. In this part of the paper it is shown when and where Kochanowski would have consulted or watched and read maps. The second part of the text compares the poem by Kochanowski and its Horatian model. The author recalls the conclusions of previous interpretations by J. Ziomek, L. Szczerbicka-Ślęk and others. Kochanowski's version is almost a translation, but the Polish poet rewrote Horace's ode in a specific way. $\mathrm{He}$ changed the ancient names of places and put in their place the names of the regions of $16^{\text {th }}$-century Europe. In the subsequent analysis, the author argues that this is not only an example of Renaissance metonomasy, but it also shows the more complex process of replacing one cartographical imagination with another. While the cartographic imagination of Kochanowski was based on the Ptolemaic tradition and its early-modern transformations, Horace's ode evokes the tradition of maps similar to the Porticus Vipsania in Augustan Rome and copies the Tabula Peutingeriana. Therefore, the metacartographies of the poets should be seen as different. The final part of the paper shows yet another difference between the two poems. While the gaze of the Roman poet goes beyond the limina of the Roman Empire, Kochanowski is looking only at the European and not very distant Mediterranean regions. The author concludes with the hypothesis that this European orientation became typical for Polish poetry of the $16^{\text {th }}$ and $17^{\text {th }}$ centuries. This Europocentric focus is one of the distinct features of Polish literature that made it different from the literatures of the countries interested in overseas colonial endeavours.

Keywords: Renaissance cartography, Jan Kochanowski, Horace, Polish Renaissance poetry, imitation, early-modern national identity, Europocentrism, cartographic reason

\section{Prologue: the humanist and the map}

Did Jan Kochanowski ${ }^{1}$ use maps? We do not know the inventory of his library, in fact we do not have his correspondence, and the dictionary created on the basis of his works does not record this word.

1 Jan Kochanowski (1530-1584) was the most important Polish Renaissance poet. He played a huge role in the creation of the modern Polish poetic language. His main works include Latin elegies (1561 and 1584), Zuzanna (1562), the tragedy Odprawa posłów greckich (1578), Psałterz Dawidów (1579), Treny (1580; contempo- 
But Kochanowski knew contemporary maps and was a man formed by cartographic thinking.

He probably used the war maps of Stanisław Pachołowiecki and Maciej Strubicz, writing his poems and poems relating to the Bathory's wars, which will be discussed in the following chapters, ${ }^{2}$ and may have also had access to maps of Russia made by Wied, Gastaldi, Herberstein and Jenkinson. He certainly used a map of the sky when he was preparing the Latin edition of the poem Aratus (based on Cicero) and translating Aratos' Phaenomena into Polish. This last edition was also provided with a map of the constellations. ${ }^{3}$ The number of cartographic sources available to Kochanowski must have been much larger, but at this point in time the question as to which maps he did or did not have access is a secondary matter.

It is during his life that the most famous cartographic works of those times were created, namely those of Ortelius and Mercator. For over a hundred years, humanists had been passionate about cartography, incorporating it into their daily reading. Renaissance humanism was based, among other things, on imagining the world by means of maps. $15^{\text {th }}$-century intellectuals did not actually use maps, or at least not the type of maps to which we and Renaissance people are accustomed. Over the course of two centuries, a radical change

rary translation into English entitled Laments: S. Heaney and S. Barańczak); Pieśni and Fraszki (published in 1585).

2 The possibility that Kochanowski used maps was indicated several decades ago by Tadeusz Ulewicz ("Świadomość słowiańska Jana Kochanowskiego. Z zagadnień psychiki polskiego Renesansu," in: idem, Świadomość słowiańska Jana Kochanowskiego. Europejskie oddziaływanie Jana Kochanowskiego, Kraków 2006, p. 123). Apart from these two cartographers, Ulewicz mentioned Bernard Wapowski, Sulimowski and rancus, and summed up the issue of Kochanowski's dealings with maps in the following way: "It is neither the time nor place to go into these details here." Since then, this question has not been developed further.

3 A reproduction of it from the collections of the Jagiellonian Library was included in Justyna Kiliańczyk-Zięba’s book: Czcionką i piórem. Jan Januszowski w roli pisarza i tlumacza, Kraków 2007, pp. 202-203. 
in the perception of space had taken place. ${ }^{4}$ In the $16^{\text {th }}$ century, maps were already everywhere, published in tens of thousands of copies in all European countries, and this process of cartographising our thinking about the world continues to this day.

For a long time, historians of cartography have asked the following questions: what happened during the two centuries between the beginning of the $15^{\text {th }}$ and $17^{\text {th }}$ centuries that resulted in maps becoming so common? What were the circumstances of the origins of cartography? They are closely related to Renaissance literature, because it is there that we find a clear reflection of the process of disseminating maps. Their appearance implies a new way of talking about space (mapping it) and, above all, placing oneself in this space. The aim of my paper is, therefore, to try to answer the question as to how the main early-modern Polish poet confronts these changes. I would like to answer the questions regarding how Kochanowski maps his world and how he uses his own cartographic writings to place himself and his nation in the world. ${ }^{5}$ A no less important question concerns what his response to mapping practices of that time was.

From the end of the $15^{\text {th }}$ century, Cracow humanists actively participated in the process of creating new European and global spaces, e.g. by defining the eastern parts of Europe. In the second half of the $16^{\text {th }}$ century the process of placing Poland and the Polish-Lithuanian Commonwealth on the global map was basically completed, but the question of negotiating for Poles a place in Europe that would meet their aspirations remained open. Sometimes this negotiation took

4 See P. D. A. Harvey, Maps in Tudor England, Chicago 1994, p. 7; D. Buisseret, The Mapmakers' Quest. Depicting New Worlds in Renaissance Europe, Oxford 2003, p. XIV; J. Pickles, A History of Spaces. Cartographic reason, mapping and the geocoded world, London-New York 2004, p. 77; R. W. Unger, Ships on Maps. Pictures of Power in Renaissance Europe, New York 2010, pp. 1-3.

5 See T. Conley, Self-made Map. Cartographic writing in early modern France, Minneapolis 1996, p. 3. 
the form of counter-mapping ${ }^{6}$ in relation to texts created in other parts of the continent.

A new metageography of Europeans ${ }^{7}$ that was emerging in this period was created under the influence of the reception of the works of Ptolemy, Strabo, Tacitus and Pliny. ${ }^{8}$ In addition to scientific works by Alexandrian and Roman authors, historical texts were also important sources, e.g. Livy and Caesar, as well as poetry. Geography and space played an important role in the work of the leading Augustinian poets, Virgil, Horace and Ovid. A large proportion of their works reflect the metageography of the times in which they lived, especially Aeneis. Humanists who imitated Roman poetry had to confront their own experiences with Roman spatial images and translate such images into their own mental maps.

\section{Kochanowski imitates a poem by Horace}

An example of such a translation is Kochanowski's song II 24 beginning with the following incipit "Endowed with a pinion that is mighty and rare." This has been analysed and mentioned many

${ }^{6}$ See J. Pickles, A History of Spaces..., pp. 179-194 for countermapping as a form of defence against mapping that imposed the interests of groups and institutions which possessed economic, political, military and symbolic power; D. Wood, Rethinking the Power of Maps, New York-London 2010, pp. 111-155.

7 Metageography is defined as "the set of spatial structures through which people order their knowledge of the world: the often unconscious frameworks that organize studies of history, sociology, anthropology, economics, political science, or even natural history," M. Lewis, K. Wigen, The Myth of Continents. A critique of metageography, Berkeley 1997, p. IX.

8 See J. Miziołek, "W poszukiwaniu wizji lepszego świata. Uwagi o recepcji kultury i nauki starożytnej Grecji we włoskim Renesansie," in: Świat Ptolemeusza. Włoska kartografia renesansowa $w$ zbiorach Biblioteki Narodowej. Wystawa $w$ stulecie urodzin Jana Zamoyskiego, red. T. Płóciennik, M. Baliszewski, Warszawa 2012, pp. 54-65.

9 Translated by Michael J. Mikoś. 
times in the last hundred and fifty years, and is one of the more famous lyrics of the poet. ${ }^{10}$ Scholars who have studied this text have discussed eight main problems, namely the question of translation, imitation and emulation, Kochanowski's Horatianism, the meaning of verses 5-6 ("that I"-ille ego), the poet's metamorphosis into Apollo's bird, the replacement of Roman realities with Polish ones (metonomasy), Kochanowski's poetic programme, especially in the context of his Muse (Kochanowski's poetic manifesto in the form of a poem-K. S.), the definition of the poet's role as an Orphean bard, and Kochanowski's relations with Myszkowski.

Song II 24 was published posthumously in 1586 by Jan Januszowski's Lazarus Printing House in Cracow together with Fraszki. It closes a cycle of two books of songs, although it is followed by a Hymn entitled Pieśń (literally: Song). Song II 24 can be treated as a summary of the cycle, and the hymn as an addition. We do not know when it was written, but researchers are willing to associate it with the last decade of his life. ${ }^{11}$

10 This ode has been discussed many times by researchers. The fullest and deepest analysis was presented by Jerzy Ziomek, "Niezwykłe i nie leda pióro," in: Jan Kochanowski. Interpretacje, red. J. Błoński, Kraków 1989, pp. 95-107. Songs were also written by, among others S. Tarnowski, Studia do historyi literatury polskiej. Wiek XVI. Jan Kochanowski, Kraków 1888, p. 314; S. Windakiewicz, Jan Kochanowski, Warszawa 1947, p. 182; J. Ziomek, Renesans, Warszawa 1977, p. 276; J. Pelc, Jan Kochanowski. Szczyt renesansu w literaturze polskiej, Warszawa 1980, pp. 227-228, 240, 376-377; M. Cytowska, “Komentarz”, in: J. Kochanowski, Dzieła wszystkie, t. 4, Pieśni, red. M. R. Mayenowa, K. Wilczewska, B. Otwinowska, M. Cytowska, Warszawa 1991, pp. 475-476; J. Abramowska, "Poeta zgody - Jan Kochanowski," in: Pisarze staropolscy. Sylwetki, t. 2, red. S. Grzeszczuk, Warszawa 1997, p. 141; P. Wilczek, "Pieśni," in: Lektury polonistyczne. Jan Kochanowski, red. A. Gorzkowski, Kraków 2001, p. 312; J. Sokolski, "Jan Kochanowski," in: Historia literatury polskiej w dziesięciu tomach, t. 2, Renesans, red. A. Skoczek, Bochnia 2002, p. 286; T. Ulewicz, Świadomość słowiańska..., p. 129; L. Szczerbicka-Ślęk, "Wstęp," in: J. Kochanowski, Pieśni, red. L. Szczerbicka-Ślęk, Wrocław 2008, pp. XXVIIXXVIII.

11 See S. Tarnowski, Studia do historyi..., p. 314; J. Pelc, Jan Kochanowski..., p. 227. 
Song 24 of Ksieggi wtóre could be called a translation of Horace's ode II 20 Non usitata nec tenui ferar, if not for a few significant shifts in meaning. Hence, it will be safer to call it an imitation or emulation. ${ }^{12}$ With his text, Kochanowski proves that the Polish language of that time already had the capacity to bear the ideas and artistry of Roman poetry of Augustinian times. And, certainly, Kochanowski was able to successfully face such a task. At the same time, he repeats in his song the gesture of Horace and at the end of the cycle he includes a commentary on his work.

It is a poem about the passing, death and immortality of the poet, the latter of which is ensured by his poetry. His death is depicted as a metamorphosis into a swan, the bird of Apollo, which will fly into the sky and, circulating above subsequent regions, will make his fame spread widely. Having a dual nature, mortal and immortal, material and immaterial, the poet "shall not wholly die." His better part will not be absorbed by the black arms of the "bleak Styx," because it will survive in his work. The funeral, described in the last stanza, will therefore serve no purpose, as the poet will still be alive.

The topoi of poetical immortality, flight, the meaning of creativity, etc. were taken in their entirety from Horace's ode and in this respect one could speak of song 24 as a translation. At the same time, however, Kochanowski introduced four fundamental changes. First of all, the poem was addressed to Bishop Piotr Myszkowski (c. 1510-1591), Kochanowski's friend and protector, to whom the poet also dedicated his paraphrase of Psalterz Dawidów (David's Psalter) and several other works. His name replaced the name of Gaius Maecenas present in Horace's ode. Secondly, the poet pointed out that he is "born with equal happiness," unlike Horace, who mentioned his lowly origin and social advancement thanks to the support of Maecenas. Thirdly, Kochanowski Christianised his version: the poet's dual nature can mean the dual nature of a man composed of an immortal soul and a mortal body. In addition, the funeral from

12 See J. Ziomek, “Niezwykłe i nie leda...," p. 98. 
the last stanza, with the "mournful voice singing mourning songs," clearly has a Catholic character. And fourthly, the regions mentioned in the fourth and fifth stanzas, above which the poet, transformed into a bird, is to fly, are different from those in the poem of the poet from Venosa. And it is precisely these last differences that I would like to take a closer look at, and on the basis of them I would like to try to answer the following question as to what cartographic image of Europe Jan Kochanowski could have had. ${ }^{13}$

Let's start with the flight of Horace and his metacartography. When I write about metacartography, I mean a term resembling the metageography mentioned above. It is an internalised set of cartographic images which serve to interpret and structure space in an imaginative and symbolic way. It is based on writing and requires at least an elementary knowledge of the map, in other words, the ability to use the map (cartoliteracy) and the ability to use the "mind" or "cartographic reason." ${ }^{4}$ The function of metacartography and cartographic reason may not only be to operate in the world with a real map, but also "alternative mapping," ${ }^{15}$ for example with the use of poetry.

13 This problem has so far escaped the attention of most scholars. Probably the first to have noticed the connection between this song and the map was Andrzej Borowski (Pojęcie i problem „Renesansu pótnocnego”. Przyczynek do geografii historycznoliterackiej humanizmu renesansowego pótnocnego, Kraków 1987, p. 6). Other authors wrote about the "flight landscape" (J. Ziomek, "Niezwykłe i nie leda...," p. 105), names that "refer to sixteenth-century reality" (P. Wilczek, "Pieśni," p. 312), "naming nations" (T. Ulewicz, Świadomość stowiańska..., p. 129), "the space of forknown fame," not limited "to the centre of Europe [only], which indicate "the territories distant from this centre" (L. Szczerbicka-Ślęk, "Wstęp," p. XXVII). This issue is interesting in that most of the interpreters of song II 24 think in maps, while not referring to this phenomenon in their texts. This is probably evidence of such a strong internalisation of the map as a certain principle that structures thinking that there is no need to point it out.

${ }_{14}$ See J. Pickles, A History of Spaces..., p. 77.

15 See E. Rybicka, Geopoetyka. Przestrzeń i miejsce we wspótczesnych teoriach i praktykach literackich, Kraków 2014, p. 149. 
In order to locate the beginning of Horace's flight, one has to go back to the beginning of the second stanza, in which Horace writes "urbis relinquam,"16 which evokes associations with Urbs-Rome and other cities on the Apennine Peninsula. In stanzas 4 and 5 we find references to nine lands. At the beginning of the fourth stanza, the names Dedalus and Icarus point to Crete and Greece as a whole. From this Greek perspective, the poet/bird looks at the nearby Bosphorus coastline. Then he looks south, towards the Getulian Sirteans, i.e. the Berberian areas north of the Atlas Mountains in Africa. In the next verse the poet's eyesight turns to the far north, i.e. to Hiperborea campos, hyperborean fields.

In the first two lines of the fifth stanza, the winged fame of Horace heads east and flies over the lands around the Black Sea, Colchis, i.e. the eastern shores of the Black Sea, and today the territory of Georgia, over Dacia, i.e. the Roman province in today's Romania. Finally, the ultimi Geloni are mentioned at the end, according to Horace, a people who live at the very ends of civilisation. Gelonians, as Herodotus writes, lived in north-western Scythia, i.e. areas east of present-day Kiev in Ukraine. ${ }^{17}$ The last two lines of this stanza show a flight westwards. The poet's work will be known to the Spanish (peritus Hiber) and a resident of the Gaul (Rhodani potor).

When we follow the flight of the poet transformed into a swan on a map, its centre will be located in Rome and Greece, while the next verses will mark out the four cardinal directions: south (Sirte), north (Hyperboreans), east (Colchis, Dacia and Gelonians), and west (the Iberian Peninsula and the Gaul). The poetic map of Horace determines the range of the influence of his poetry and thus his immortality. ${ }^{18}$ This immortality is geographically conditioned, extending

16 Quotations from Horace's ode following: Q. Horatius Flaccus, Opera, Bd. 2, hg. von F. Klingner, Leipzig 1970, p. 64.

17 See Herodot, Dzieje, tłum. S. Hammer, Warszawa 2007, p. 262.

18 Commentators on Horace's work did not write about the cartographic dimension of his poetry, but they paid attention to all the directions of the world in 
as far as the Latin language and the Roman Empire reach. Horace writes in similar terms about his legacy in the last ode, which closes the original three-book edition, namely the famous ode III 30 Exegi monumentum. There, however, immortality was not limited territorially, but temporally. The fame of Horace is to last as long as Rome.

\section{Kochanowski imitates the map of Horace}

Kochanowski repeats Horace's gesture, but in a different space. Kochanowski writes in the fifth verse: "I shall disdain cities," but unlike in Horace's case, it is not easy for us to identify these cities. Although it is difficult to suppose that he was concerned with Rome, one cannot say that it was Cracow. We should rather understand this phrase as another gesture of Horace, a contempt for large groups of envious people. It can be assumed, however, that Kochanowski, who writes in Polish, starts his flight in Poland.

Where is the bird from Kochanowski's poem flying then? In the fourth stanza he follows the same path as the Horatian bird: Greece, the Bosporus, the Syrtes, although the names have been slightly changed. Cyrene (Kyrene) is a city in North Africa in modern-day Libya. The area geographically corresponds to that of the Getulian Syrtes from Horace's ode. In turn, the Horatian Hyperborean lands were replaced by the northern territories, the Polonised version of Septemtriones, that is, the seven stars of the constellation of the Great or Little Plough. In both cases it is far north.

Kochanowski used the equivalents of the original names and thus began an emulatory game with Horace. It is not the first time in his work that he seems to say, "I can write in Polish what Horace wrote in Latin, that is, I can translate Horace into Polish." However, the

which the poet's posthumous fame is to spread, see R. G. M. Nizbet, M. Hubbard, A Commentary on Horace's Odes: Book II, Oxford 1978, p. 347. 
equivalence of the names in the fourth stanza has a different meaning: "I can write in Polish as if it were written by Horace." In the fifth stanza, Kochanowski proves, however, that his emulation can go even further: "I can express in Polish what Horace could have written if he had lived in my times." Kochanowski replaces the map of Horace:

Moscow and the Tatars will know about me, And Englishmen inhabiting various corners of the world, I will be known to the Germans and brave Spaniards, Who drink from the deep stream of Tiber. ${ }^{19}$

On the face of it, Kochanowski's map is disordered, and the directions of the spread of his poetic fame are determined by chance. Nevertheless, we find order in it. The presupposition is the location of Poland not mentioned in the poem: it is in the centre. The bird that begins its flight there first visits the Slavs closest to Poles, that is, the Muscovites. They should get to know the poet's works sooner than anyone because of the similarity of the languages.

Kochanowski used an understanding of space characteristic of his times. Therefore, the Muscovites do not inhabit the east, as we are accustomed to locate them today, but in the far north. Hence, they are a reflection of the Horatian Gelonians. Then he lists the Tatars, who according to the $16^{\text {th }}$-century geographical imagination were placed in the east. They are followed by the north-western Englishmen and Germans, western Spaniards and southern Italians. They replaced the Rhône-drinking Gauls from Horace's ode.

19 This and other quotations from Kochanowski's poem (unless otherwise marked in footnotes) are translated by Kaja Szymańska. A full translation of the poem by Michael J. Mikoś is attached at the of the paper. 


\section{Counter-mapping by Kochanowski}

Kochanowski's cartographic activity apparently boils down only to redrawing the Horatian map. Apparently, it consists in shifting the centre and fixing directions in a new way. In Horace's ode, there is the Mediterranean oecumene, ${ }^{20}$ whose central places are Rome and Greece. The known world is limited to the Roman Empire and its limes. In Kochanowski's song the Mediterranean oecumene has been replaced by Europe. While Horace's gaze is Romocentric, Kochanowski's gaze is Eurocentric. ${ }^{21}$ In this limitation to "their own" territories, a certain common feature can be discerned. Poetic mapping of the oecumene by both poets serves not so much to describe it, as to create a community and define the foundations of geographical and cultural identity.

Kochanowski's poetic mapping in the fifth stanza is not, however, a palimpsest. He does not put his more or less modified version on Horace's map, which happens in the fourth stanza, and he does not even correct it. Rather, as I mentioned earlier, he replaces the Horatian map with his own, or actually counter-maps it. The last two lines of the fifth stanza are crucial: "They who drink from the deep stream of Tiber / will learn about me." The swan from Horace's poem looks at the "Hyperborean lands" from a distance, and its fame reaches the "furthest" Gelonians (ultimi Geloni), i.e. where in the future the territory of, among other place, the Polish-Lithuanian Commonwealth will be located. Their inhabitants are on the verge of the oecumene

20 The word oecumene is used here in the original Greek sense. Andrzej Frycz Modrzewski explains this as follows: "what applies to the whole earth is common, and oecumene means the whole world, that is, the whole inhabited earth," A. Frycz Modrzewski, O poprawie Rzeczypospolitej (IV, 3).

21 Another humanist and Polish writer Jan Dantyszek (1485-1548) approached the European oecumene in a similar way, see A. Borowski, Iter Polono-BelgoOllandicum. Cultural and Literary Relationships between the Commonwealth of Poland and the Netherlands in the $16^{\text {th }}$ and $17^{\text {th }}$ centuries, Cracow 2007, pp. 38-52. 
or even, as in the case of the Hyperboreans, beyond the borders of civilisation.

Meanwhile, in Kochanowski's song, it is precisely those distant and unrecognised lines or places outside the limes imperii Romani that take over the central position. He moves the areas by the Vistula and Dnieper Rivers to the middle of his map. In cartographic rhetoric, the position of an object, its graphic size, the type of font used, the placement or omission of an object or toponym is of fundamental importance for the interpretation of space. ${ }^{22}$ Above all, this involves expressing dominance and identifying the centres and peripheral areas. On Jan Kochanowski's map of Europe, the central position is occupied by the Polish-Lithuanian Commonwealth while the peripheral position is held by Rome. At the very end, Kochanowski's swan will arrive at the place from which Horace's swan started its flight. Thus Kochanowski reverses the Horatian order of things by reorganising spatial relations, i.e. by counter-mapping. Kochanowski shows that the world has changed and Horace's map is no longer up to date. The very gesture of mapping the oecumene remains, but now oecumene means something else. The topos of mapping remains unchanged, but the language of poetry and metageography are completely different. Kochanowski's mapping is therefore immersed in history because it reflects the variability of the map. Jerzy Ziomek has noted that Kochanowski's gesture of moving places of future fame is based on historical thinking. According to him, the future of Horace was a past time for Kochanowski. It is therefore necessary to come up with a new territory for the future. It is the territory of nations.

Kochanowski expresses the view that there is a certain community of early modern Europe, which is at the same time a Europe of states and nations. Kochanowski's poem once again harmonies with $16^{\text {th }}$-century cartography. According to contemporary researchers,

22 See J. B. Harley, "Maps, Knowledge, and Power," in: idem, The New Nature of Maps. Essays in the history of cartography, ed. by P. Laxton, Baltimore-London 2001, pp. 66-71. 
the main driving force behind its development was the beginnings of the modern nation state and capitalist economy. ${ }^{23}$ In Kochanowski's poem, however, the determinants of these kingdoms are not borders, as on contemporary maps, but the names of countries and the rivers and cities associated with them, as on Gerard Mercator's map of the world. Regardless of the spatial determinants used, Kochanowski's European oecumene radically differs from Horace's imperial oecumene.

\section{Two different metacartographies, i.e. imitation impossible}

There is one more fundamental difference between the meta-cartographies of the two poets. At first glance, the replacement of names in Kochanowski's poem is an example of Renaissance metonomasy, i.e. "the transfer of a name from one nomenclature system (of a given time and space) to another nomenclature system (of a different time and another space)." ${ }^{24}$ It seems, however, that this change is much more important. We can only see it from our own contemporary perspective of readers living in the $21^{\text {st }}$ century.

It does not matter whether we chart Kochanowski's poetic map using today's Google Maps or the Mercator map. The result will be

23 "Although the details of the development and use of maps are very complex and regionally differentiated, we can say that there have been major changes in Europe between 1400 and 1600 in terms of the form, use and accessibility of maps. What is more, these changes, resulting in a radical change in cartographic consciousness, had a significant impact on the formation of a new national state consciousness (and were themselves subject to its influence). Its constitutive features were the concern for the establishment, defence and management of the national territory and the administration of the national economy," J. Pickles, A History of Spaces..., p. 77. See also D. Wood, Rethinking the Power..., p. 9.

24 J. Ziomek, "Niezwykłe i nie leda...," p. 103. 
more or less the same-a clear European outline with countries and peoples, major rivers and the same major urban centres: Budapest, Vienna, Moscow and Cracow. The metacartography of humanists living in the $16^{\text {th }}$ century and scholars who lived five hundred years later is convergent in many points. Nevertheless, the metacartography of Horace and his Polish imitator differ diametrically. The reason for this difference is, first of all, the fact that the maps that Horace knew probably had a form completely different from those used by humanists in the Renaissance. Horace would probably not recognise our maps and would not be able to use them. This is related to the cartographic revolution that took place about one hundred and fifty years after his death.

The person responsible for this revolution was one of the most influential figures in the history of science, the Alexandrian scholar Claudius Ptolemy (c. 100-168). ${ }^{25}$ Among his main works is Geography, written in Greek, which describes ways of representing the spherical world on a plane, i.e. the principles of cartography. Most probably, Ptolemy mapped the whole world known to him in his work. His conic projection, based on geometric construction, aroused the fascination of $15^{\text {th }}$-century humanists. The reception of Ptolemy's treatise is reminiscent of the reception of other ancient texts that were discovered in the $15^{\text {th }}$ century, or example the Institutio oratorios by Quintilian, the poetry of Catullus, Geographica by Strabo and Germania by Tacitus, but the significance of Ptolemy's treatise was incomparably more important; historians of science even use the term "Ptolemaic revolution."26 After Ptolemy's Geography

25 See O. A. W. Dilke with additional material supplied by the editors, "The Culmination of Greek Cartography in Ptolemy," in: The History of Cartography, vol. 1. Cartography in Prehistoric, Ancient and Medieval Europe and the Mediterranean, ed. by J. B. Harley, D. Woodward, Chicago-London 1987, pp. 177-200; A. Jones, Ptolemy's Geography: Mapmaking and the scientific enterprise, ancient perspectives. Maps and their place in Mesopotamia, Egypt, Greece and Rome, ed. by R. J. A. Talbert, Chicago-London 2012, pp. 109-128.

26 See J. Babicz, "La Résurgence de Ptolémée," in: Gerard Mercator cosmographe: Le temps et l'espace, éd. M. Watelet, Antwerp 1994, pp. 50-69; Ch. Jacob, The 
entered into circulation, representatives of the European intellectual elites began to imagine the world in a way completely different from their predecessors living in previous centuries.

Ptolemy's treatise, translated into Latin, repeatedly rewritten and then printed, found itself at the centre of the humanists' interest. Every educated man living in the second half of the $15^{\text {th }}$ and early $16^{\text {th }}$ century knew Latin translations of Ptolemy's texts or at least discussions on them that took place at universities. ${ }^{27}$ The mathematical, geometrised projection of the world by Ptolemy was the basis on which $16^{\text {th }}$-century cartographers, among others, drew their maps. ${ }^{28}$ His map of Europe in manuscripts and prints from the $15^{\text {th }}$ and $16^{\text {th }}$ centuries does not differ much from the maps created by cartographers active at that time. This is a direct result of the fact that they learnt to reproduce the world from his Geography. Most of them, such as Waldseemüller, Beneventano, Wapowski, Ortelius and Mercator, had experience in editing the maps of Ptolemy. However, they paid little attention to the means of cartographic representation that Horace might have come into direct contact with, perhaps because they knew little or nothing about them.

Sovereign Map. Theoretical approaches in cartography throughout history, transl. by T. Conley, ed. by E. H. Dahl, Chicago-London 2006, pp. 62-63; G. Dalché, "The Reception of Ptolemy's Geography (End of the Fourteenth to Beginning of the Sixteenth Century)," in: The History of Cartography, vol. 3, Cartography in the European Renaissance, p. 1, ed. by D. Woodward, Chicago-London 2007, pp. 285-286.

27 The commentators on Ptolemy at the University of Cracow at the turn of the $15^{\text {th }}$ and $16^{\text {th }}$ centuries included Jan of Głogów and Jan of Stobnica. The latter issued an introduction to Comography: Introductio in Ptolemei Cosmogrpahiam cum longitudinibus et latitudinibus regionum et civitatum celebriorum, Cracoviae 1512. See T. Ulewicz, Sarmacja. Studium z problematyki słowiańskiej XV i XVI w., Kraków 1950, pp. 41-42; J. Bzinkowska, Od Sarmacji do Polonii. Studia nad początkami obrazu kartograficznego Polski, Kraków 1994, p. 9; K. N. Piechocki, "Erroneous Mapping: Ptolemy and the Visualisation of Europe's Est," in: Early Modern Cultures of Translation, ed. by K. Newman, J. Tylus, Washington 2015, pp. 84-86.

28 N. J. W. Thrower, Maps and Civilization. Cartography in Culture and Society, Chicago-London 1996, pp. 58-59, 69-75, 81. 
We also know relatively little about the cartography of ancient Rome, especially during the Augustinian period. Sources say that the Romans used maps, but we can only speculate what they looked like. Sources concerning Roman maps date back no further than the late Roman period. ${ }^{29}$ More information can be found in later sources, including Porticus Vipsania.

This was built by Vipsania Polla, sister of Marcus Agrippa (63-12 $\mathrm{BC})$, the Roman commander and minister of Octavianus Augustus. The construction of Vipsania's Portico at Via Lata in Rome, the urban section of Via Flaminia, began before Agrippa's death and was continued by Augustus after 12 BC. It was a remarkable monument of authority containing a roadmap of the Roman state engraved on marble slabs. The importance of cartography in propaganda had already been recognised several decades earlier, but it was Julius Caesar and Octavianus who commissioned the cataloguing and mapping of the territories conquered by the Romans. ${ }^{30}$ The Porticus Vipsania is probably one of the results of these undertakings. On the basis of the description of the building provided by Pliny the Elder in Historia naturalis, it is assumed that the map was similar to road maps or road descriptions. ${ }^{31}$

A much later example of a Roman road map is the Peutingerian Tabula, kept in Vienna. It has been preserved in a copy from the $13^{\text {th }}$ century. For several decades there has been a dispute over the period when it was created, but most historians of cartography assume that it is probably a copy of a road map of the Roman Empire from the $4^{\text {th }}$ century AD. ${ }^{32}$

29 See O. A. W. Dilke, "Maps in the Service of the State: Roman Cartography to the End of the Augustan Era," in: The History of Cartography, vol. 1, Cartography in Prehistoric, Ancient and Medieval Europe and the Mediterranean, ed. by J. B. Harley, D. Woodward, Chicago-London 1987, p. 204.

30 See ibidem, p. 205.

31 See ibidem, pp. 207-208.

32 Codex Vindobonensis, Austrian National Library, Ref. 324. See also L. Bosio, La Tabula Peutingeriana. Una descrizione pittorica del mondo antico, Rimini 1983, 
We do not know if Horace saw maps similar to those depicted in the Porticus Vipsania. Although it was opened to the public in 7 $\mathrm{BC}$, i.e. one year after his death and 16 years after the publication of Ode II 20 (23 BC), the maps depicted on it were not created from scratch. They were based on earlier road maps, which the Romans used to travel around the empire. They are referred to as itinerarium pictum $^{33}$ as opposed to itinerarium scriptum, which contained only text. In both cases, it was a long scroll on which the distances between particular towns, which were located by the main roads of the state, were marked.

A map from the National Library in Vienna, which reflects almost the entire world known to the Romans, i.e. areas from North Africa to the British Isles and from Spain to India, was depicted on a belt 675 centimetres long and only 34 centimetres wide. The extent of the distortion is therefore large, as can be seen from the example of the Mediterranean Sea, which has been squeezed or stretched so that the horizontally depicted heel of the Italian boot almost touches Dalmatia, and the Nile delta is located directly under Anatolia and Lebanon.

Although such cartographic representations might have been known to Horace, we do not know whether he had knowledge of mathematical maps, divided with a grid of meridians and parallels similar to those which Ptolemy designed more than a hundred years after the poet's death. We do not even know whether the geographical coordinates given in Greek-language treatises were used to create maps in antiquity. Historians of cartography have pointed out that

150-162; F. Prontera, "La Tabula Peutingeriana nella storia della cartografia antica," in: Tabula Peutingeriana. Le antiche vie del mondo, a cura di F. Prontera, Firenze 2003, pp. 17-23, R. J. A. Talbert, Rome's World: The Peutinger Map Reconsidered, Cambridge 2010, p. 7.

33 See O. A. W. Dilke, "Itineraries and Geographical Maps in the Early and Late Roman Empires," in: The History of Cartography, vol. 1, Cartography in Prehistoric, Ancient and Medieval Europe and the Mediterranean, ed. by J. B. Harley, D. Woodward, Chicago-London 1987, p. 238. 
antique books were in the form of scrolls and therefore the physical creation of as the sort of map designed by Ptolemy was technically impossible without large distortions (as we are dealing with on the Tabula Peutingeriana). Maps, which we recognise today as Ptolemaic, could not be created until after the invention of the book in the form of the codex..$^{34}$

Therefore, we are not sure whether Horace could have imagined the Mediterranean coasts in a way similar to Kochanowski or us. This is rather improbable.

Unlike Horace, Kochanowski is unlikely to have seen Roman roadmaps, even though Tabula Peutingeriana was known during his lifetime. It was discovered in Worms by Conrad Celtes and before his death passed on to another well-known humanist, Konrad Peutinger (1465-1547). In the second half of the $16^{\text {th }}$ century it was copied for Abraham Ortelius, who planned to publish it. The first edition was first published in part in 1591, and in its entirety in 1598 , i.e. more than a decade after Kochanowski's death. ${ }^{35}$ It is therefore unlikely that Kochanowski knew this work. Like every humanist, however, he was familiar with the tradition of Ptolemaic cartography. By the middle of the $16^{\text {th }}$ century, 26 editions of Geography with a total circulation of several thousand copies had been published, ${ }^{36}$ and, as already mentioned, modern cartography is largely derived from the $15^{\text {th }}$-century editions of this work. Based on Ptolemy and possibly also on the Eurocentric Pliny (whom Horace could not have known either and whom Kochanowski certainly read), the metacartography of the Polish poet was fundamentally different from that of Horace, which was based on narrative sources, chorographies and perhaps on some form of maps, such as itin-

34 A. Jones, "Ptolemy's Geography: A reform that failed," in: Ptolemy's Geography in the Renaissance, ed. by Z. Shalev, Ch. Burnett, London-Turin 2011, p. 18.

35 M. van den Broecke, Ortelius Atlas Maps. An illustrated guide, Houten 2011, pp. 668-673.

36 See J. Bzinkowska, Od Sarmacji do Polonii..., pp. 106-108. 
eraria picta. In the case of Horace the perception of space is essentially textual and perhaps linear, and in the case of Kochanowski it is textual-pictorial (i.e. two-dimensional) and perhaps additionally geometric in character. The differences between their "poetic-cartographic" representations are therefore not only due to changes in the political system and the cultural, political and economic centres being moved to the north. The main difference was in the way they represented space visually. Both poets thought of using an internalised map, but the spatial relationships they expressed were utterly different. Humanists only learnt to think pictorially about space under the influence of publications in the second half of the $15^{\text {th }}$ century and as a result of commenting on maps created on the basis of Ptolemy's treaty. ${ }^{37}$ At Kochanowski's time this process had already ended.

A traditional philological comparison of song 24 from Ksiegi wtóre with ode II 20 reveals mainly lexical shifts. So it would be an example of the Renaissance metonomasy discussed by Ziomek. These shifts consist in "replacing" Latin names with Polish ones and other imitation procedures, ingeniously and skilfully carried out in the Polish poem. They were so successful (in this as well as other of his poems) that Kochanowski posthumously gained the nickname "the Polish Horace." His translation (if we consider it only as a work of literature, not a map) took place in two spaces. It was the "transfer" or "resettlement" (translatio) of words and phrasemes from one language to another (i.e. translation). Moreover, it was also the "resettlement" of a set of ideas and poetic forms into a different cultural reality, which was in turn transformed itself. After such implantation of Horace's words and thoughts, Polish poetry underwent a fundamental metamorphosis. ${ }^{38}$ Philological comparisons of poems by Ro-

37 See D. Woodward, "Cartography and the Renaissance: Continuity and change," in: The History of Cartography, vol. 3, Cartography in the European Renaissance, p. 1, ed. by D. Woodward, Chicago-London 2007, pp. 3-6.

38 See J. Pelc, Jan Kochanowski..., p. 502. 
man and Polish poets allow us to understand how this implantation was carried out.

However, reading both poems in the context of cartography enables us to see semantic substitutions on deeper levels. The "Getulian Syrtes" are different from the "Cyrenean syrtes" not because of the different epithet, but because the spatial imagination of the people living in the $16^{\text {th }}$ century functioned differently from the imagination of the Romans. This difference originated in the cartography that was developing in the $16^{\text {th }}$ century. The swan of Horace, together with the Augustan readers of his poem, rising above the Mediterranean Sea "saw" the space down below in a completely different shape from us, the readers of Kochanowski's poem with a cartographic imagination that formed under the influence of Ptolemy's reception. In other words, before Kochanowski and his educated readers began reading or translating Horace's text, they already had certain cartographic and geographical pre-assumptions (metacartography, metageography, a cartographic mind).

These pre-assumptions in the perception of space are the result of education, among other things. They are acquired by everyone who in the course of their education acquires cartographic literacy (cartoliteracy). It is a process similar to the acquisition of literacy or simply functioning in a literate society. The mind of a man subjected to the technology of writing changes and differs from the mind of a man who has never come into contact with writing. ${ }^{39}$ The same applies to metacartography. Whoever knows the idea of a map and has become acquainted with real maps, thinks about space and his place in it differently from a person who has never had to deal with a map. The way we imagine the world therefore depends on which mapping system we are in contact with. ${ }^{40}$

39 See J. Goody, The Domestication of the Savage Mind, Cambridge 1977; idem, Logika pisma a organizacja społeczeństwa, tłum. i red. G. Godlewski, Warszawa 2006.

40 See J. Pickles, A History of Spaces..., p. 61. 
The writing technology available to Horace and Kochanowski (and other Christian Europeans) was similar. They read from left to right, used an alphabetical system, and used an alphabet with identical graphic bases and were familiar with similar handwriting techniques, etc. They also shared a cartographic view, a visualisation of space seen from a bird's eye view or with the help of the "divine eye." But the cartographic representations known to them were different and therefore their cartographic literacy differed significantly.

Therefore, while in relation to the translation of concepts we can speak of metonomasy, when it comes to spatial imaging metonomasy ceases to be functional. Among the names mentioned by Horace, there is another metacartography, incompatible with that of Kochanowski. Since the two poets had completely different ways of thinking about space, Kochanowski was not able to "translate" the Horatian map into his own. However, using his spatial imagination and words taken from Horace, he was able to construct his new European metacartography. And this is precisely what he did.

\section{Kochanowski's Eurocentrism, i.e. countermapping once again}

There is, however, one more feature that distinguishes Kochanowski from Horace. In his poem, the Horace maps the Roman Empire, but his gaze extends far beyond the borders of the known world, to the lands of the Gelonians and the Hyperboreans. Meanwhile, Kochanowski looks at nothing more than Europe and its bordering areas, Asia Minor and North Africa. Its geographical horizon is exactly within the same limits as can be seen in the famous cartographic

${ }^{41}$ See T. Conley, Self-made Map..., p. 13; J. Pickles, History of Spaces..., pp. 75, 80; D. Cosgrove, Geography and Vision. Seeing, Imagining and Representing the World, London-New York 2008, p. 25. 
image of Europa Regina of Johannes Putsch from 1537, later disseminated by Sebastian Münster.

Kochanowski knew about the newly discovered continents and their exploration, but his gaze is almost exclusively Eurocentric. Unlike the French, Portuguese or English poets, he is not interested in colonial expansion. The only trace of geographical discoveries is the expanded epithet of "the inhabitants of various corners of the world" with which he characterised the English. However, it is not the inhabitants of distant regions of the earth who will get to know the poetry of the author of Treny (Laments). For him, what counts is only Europe and its European fame, as if it were the most important thing for him to establish his position in relation to the representatives of older European cultures. At the same time, it is also the establishment of the position of the state. In this way Kochanowski's text is inscribed into $16^{\text {th }}$-century cartographic practices, one of the main objectives of which was to serve the state. The shift of the centre from Rome to the Commonwealth present in song II 24, can therefore be interpreted as negotiating Poland's place in Europe, which is also a form of countermapping. $16^{\text {th }}$-century authors (not only Kochanowski, but also Du Bellay) had to face in some way the burden of the Mediterranean heritage of Italy and antiquity. If Kochanowski saw maps of Europe, such as Battista Agnesi's portolan chart from the library of Sigismund II Augustus, ${ }^{42}$ he clearly saw that the coordinate grid always has an axis in the Mediterranean region, while Poland is just on the continent's border or does not exist at all. ${ }^{43}$ Kochanowski's translation is therefore a correction of erroneous ancient and, to some extent, modern maps, which located Poland on the outskirts of European civilisation. In this way, Kochanowski emphatically repeated the gesture of Maciej of Miechów, who half

42 Jagiellonian Library, MS 1886.

43 See C. Astengo, "The Renaissance Chart Tradition in the Mediterranean," in: The History of Cartography, vol. 3, Cartography in the European Renaissance, p. 1, ed. by D. Woodward, Chicago-London 2007, p. 194. 
a century earlier proved that there are no Riphaean Mountains in Mazovia or Lithuania. ${ }^{44}$

It seems that this limitation of geographical horizons by Kochanowski was characteristic of most of the later old-Polish writers, whose metageography usually ended at the level of the countryside or city, county, the Kingdom of Poland or the Grand Duchy of Lithuania, the Polish-Lithuanian Commonwealth or Europe, sometimes extending to Asia or North Africa (see the works of Miaskowski, Sarbiewski, Twardowski, Morsztyn, Potocki, etc.). ${ }^{45}$ This distinguishes them from the writers from the times of Sigismund I the Old. Wawrzyniec Korwin, the author of the Epitalamium for the 1518 wedding of Sigismund I the Old and Bona Sforza, ordered the winged female character of his poem, Pheme, to spread the fame of the Polish king wherever she went. Like Kochanowski, he mapped Europe, but at the end of the poem, when Pheme reaches Spain, he orders her to board a ship and sail to the New World. ${ }^{46}$ No less open to new geographical discoveries were Jan Dantyszek ${ }^{47}$ and Marcin Kromer. It would be worth considering what cultural changes taking place in Poland in the $16^{\text {th }}$ century prompted Polish writers and political elites to create a Eurocentric metageography. Probably one of the reasons was the inability to become independent from Roman and Italian literature throughout the $17^{\text {th }}$ century. On the one hand, admiration, on the other hand, the willingness to manifest their otherness made Polish writers remain in a dichotomous relationship between them and Europe (= Mediterranean culture). It is possible that this was to some

44 See K. N. Piechocki, “Erroneous Mapping...,” pp. 88-92.

45 This Europe-oriented focus of old-Polish writers was pointed out by Janusz Tazbir ("Szlachta a konkwistadorzy. Opinia staropolska wobec podboju Ameryki przez Hiszpanię," in: idem, Prace wybrane, t. 3, Sarmaci i świat, Kraków 2001, p. 30) i Andrzej Borowski (Pojęcie i problem..., p. 103; Powrót Europy, Kraków 1999).

46 See W. Korwin, Ad Famam, in: J. Niedźwiedź, "Podróż sławy Zygmunta Starego do Nowego Świata. Wawrzyńca Korwina Ad Famam,” Terminus 3 (2001), pp. 243-255.

47 See J. Tazbir, “Szlachta a konkwistadorzy...," pp. 37, 71. 
extent related to Pliny's reception, who, unlike other Greek and Roman writers, focussed his attention on Europe. ${ }^{48}$

It should be remembered that the Eurocentrism of Polish literature was different from that of the representatives of other early modern European literatures, created by Pierre Ronsard, Luís Vaz de Camões, Pedro Calderón de la Barca, and John Donne. They belonged to nations that created their identity through imperial aspirations and overseas expansion, among other things. However, it is probably not only in this fact that we should see the difference in the "creation of space, nation and self," mentioned above. ${ }^{49}$ In the case of Polish literature, this difference can be defined by the early modern system of literary metageography, defined not only by political and economic categories (e.g. colonial expansion) and historical and literary categories (e.g. the evolution of poetic forms), but also by spatial ones. Speaking of spatial categories, I mean such juxtapositions of geographical oppositions as south-north, Mediterranean culture-transalpine culture, the Italian Renaissance-northern Renaissance and the translation of ideas present in the literature of the Apennine Peninsula and its aesthetics into the literature of the basins of the Vistula, Niemen and Dnieper.

A new experience of cultural space based on cartographic thinking was formed in Polish literature during the $16^{\text {th }}$ century. The experience shaped at that time settled in the language of Polish poetry and prose for a very long time, and the world most often ended (and still does so) within the borders embraced by Queen Europe, just as in the $16^{\text {th }}$-century woodcut. Kochanowski's song "Endowed with a pinion that is mighty and rare" ("Niezwykłym i nie leda piórem opatrzony"), which is multidimensional not only in the sense of the two-dimensionality of the map, allows us to penetrate this process of forming the "spatial myths verbalised in literary creation." 50

Translated by Kaja Szymańska

48 T. Conley, Self-made Map..., p. 3.

49 A. Borowski, Pojęcie i problem..., p. 29.

50 Ibidem. 


\section{Song XXIV}

Endowed with a pinion that is mighty and rare,

A poet of two forms, I take to the air:

I will not remain on this earth any longer,

But, above envy, I will look with disfavour

At crowded cities. Not I, the one lowly-born,

Not I, whom you call your friend, by Death shall be borne,

Dear Myszkowski, nor will I be held prisoner

By the black arms of the mournful Stygian water.

At once with rough skin my shins are being covered,

At once my crown is turning into a white bird,

Small feathers are sprouting all over my fingers

And enormous wings are growing from my shoulders.

Even now, more swiftly than courageous Icarus,

I'll visit the bare shores of the loud Bosporus

And Syrtes, the bird consecrated by the Muses,

And the plains far beyond the northern territories.

Moscow and the Tartars will find out about me

And the English who live in a far-off country,

Germans, brave Spaniards will hold me in high esteem,

And those who drink water from the Tiber's deep stream.

Let there be no sobs at my empty funeral,

Nor any laments or any complaints at all:

Forego candles, bells, and a richly adorned gravestone,

Also psalms that are chanted in a wailing tone. ${ }^{51}$

\section{Bibliography}

Abramowska J., "Poeta zgody - Jan Kochanowski," in: Pisarze staropolscy. Sylwetki, t. 2, red. S. Grzeszczuk, Warszawa 1997, pp. 71-147.

Astengo C., "The Renaissance Chart Tradition in the Mediterranean," in: The History of Cartography, vol. 3, Cartography in the European Renaissance, p. 1, ed. by D. Woodward, Chicago-London 2007, pp. 174-262.

${ }_{51}$ J. Kochanowski, Trifles, Songs, and Saint John's Eve Song, transl. by M. J. Mikoś, ed. by M. Hanusiewicz-Lavallee, Lublin 2018. 
Babicz J., "La Résurgence de Ptolémée," in: Gerard Mercator cosmographe : Le temps et l'espace, éd. M. Watelet, Antwerp 1994, pp. 50-69.

Borowski A., Iter Polono-Belgo-Ollandicum. Cultural and Literary Relationships between the Commonwealth of Poland and the Netherlands in the $16^{\text {th }}$ and $17^{\text {th }}$ centuries, Cracow 2007.

Borowski A., Pojęcie i problem „, Renesansu północnego”. Przyczynek do geografii historycznoliterackiej humanizmu renesansowego pótnocnego, Kraków 1987.

Borowski A., Powrót Europy, Kraków 1999.

Bosio L., La Tabula Peutingeriana. Una descrizione pittorica del mondo antico, Rimini 1983.

Broecke M. van den, Ortelius Atlas Maps. An illustrated guide, Houten 2011.

Buisseret D., The Mapmakers' Quest. Depicting New Worlds in Renaissance Europe, Oxford 2003.

Bzinkowska J., Od Sarmacji do Polonii. Studia nad początkami obrazu kartograficznego Polski, Kraków 1994.

Conley T., Self-made Map. Cartographic writing in early modern France, Minneapolis 1996.

Cosgrove D., Geography and Vision. Seeing, Imagining and Representing the World, London-New York 2008.

Cytowska M., “Komentarz”, in: J. Kochanowski, Dzieła wszystkie, t. 4, Pieśni, red. M. R. Mayenowa, K. Wilczewska, B. Otwinowska, M. Cytowska, Warszawa 1991.

Dalché G., "The Reception of Ptolemy's Geography (End of the Fourteenth to Beginning of the Sixteenth Century)," in: The History of Cartography, vol. 3, Cartography in the European Renaissance, p. 1, ed. by D. Woodward, Chicago-London 2007, pp. 285-364.

Dilke O. A. W., "Itineraries and Geographical Maps in the Early and Late Roman Empires," in: The History of Cartography, vol. 1, Cartography in Prehistoric, Ancient and Medieval Europe and the Mediterranean, ed. by J. B. Harley, D. Woodward, Chicago-London 1987, pp. 234-257.

Dilke O. A. W., "Maps in the Service of the State: Roman Cartography to the End of the Augustan Era," in: The History of Cartography, vol. 1, Cartography in Prehistoric, Ancient and Medieval Europe and the Mediterranean, ed. by J. B. Harley, D. Woodward, Chicago-London 1987, pp. 200-211.

Dilke O. A. W., “The Culmination of Greek Cartography in Ptolemy, in: The History of Cartography, vol. 1, Cartography in Prehistoric, Ancient and Medieval Europe and the Mediterranean, ed. by J. B. Harley, D. Woodward, Chicago-London 1987, pp. 177-200.

Goody J., Logika pisma a organizacja społeczeństwa, tłum. i red. G. Godlewski, Warszawa 2006.

Goody J., The Domestication of the Savage Mind, Cambridge 1977. 
Harley J. B., "Maps, Knowledge, and Power," in: J. B. Harley, The New Nature of Maps. Essays in the history of cartography, ed. by P. Laxton, Baltimore-London 2001, pp. 51-81.

Harvey P. D. A., Maps in Tudor England, Chicago 1994.

Herodot, Dzieje, tłum. S. Hammer, Warszawa 2007.

Horatius Flaccus, Opera, Bd. 2, hg. von F. Klingner, Leipzig 1970.

Jacob Ch., The Sovereign Map. Theoretical approaches in cartography throughout history, transl. by T. Conley, ed. by E. H. Dahl, Chicago-London 2006.

Jan of Stobnica, Introductio in Ptolemei Cosmogrpahiam cum longitudinibus et latitudinibus regionum et civitatum celebriorum, Cracoviae 1512.

Jones A., "Ptolemy's Geography: A reform that failed," in: Ptolemy's Geography in the Renaissance, ed. by Z. Shalev, Ch. Burnett, London-Turin 2011, pp. 15-30.

Jones A., Ptolemy's Geography: Mapmaking and the scientific enterprise, ancient perspectives. Maps and their place in Mesopotamia, Egypt, Greece and Rome, ed. by R. J. A. Talbert, Chicago-London 2012.

Kiliańczyk-Zięba J., Czcionka i piórem. Jan Januszowski w roli pisarza i tłumacza, Kraków 2007.

Kochanowski J., Trifles, Songs, and Saint John's Eve Song, transl. by M. J. Mikoś, ed. by M. Hanusiewicz-Lavallee, Lublin 2018.

Korwin W., Ad Famam, in: J. Niedźwiedź, "Podróż sławy Zygmunta Starego do Nowego Świata. Wawrzyńca Korwina Ad Famam," Terminus 3 (2001), pp. $243-$ 255.

Lewis M., Wigen K., The Myth of Continents. A critique of metageography, Berkeley 1997.

Miziołek J., "W poszukiwaniu wizji lepszego świata. Uwagi o recepcji kultury i nauki starożytnej Grecji we włoskim Renesansie," in: Świat Ptolemeusza. Włoska kartografia renesansowa $w$ zbiorach Biblioteki Narodowej. Wystawa $w$ stulecie urodzin Jana Zamoyskiego, red. T. Płóciennik, M. Baliszewski, Warszawa 2012, pp. 54-65.

Nizbet R. G. M., Hubbard M., A Commentary on Horace's Odes: Book II, Oxford 1978.

Pelc J., Jan Kochanowski. Szczyt renesansu w literaturze polskiej, Warszawa 1980.

Pickles J., A History of Spaces. Cartographic reason, mapping and the geocoded world, London-New York 2004.

Piechocki K. N., "Erroneous Mapping: Ptolemy and the Visualisation of Europe's Est," in: Early Modern Cultures of Translation, ed. by K. Newman, J. Tylus, Washington 2015, pp. 78-96.

Prontera F., "La Tabula Peutingeriana nella storia della cartografia antica," in: Tabula Peutingeriana. Le antiche vie del mondo, a cura di F. Prontera, Firenze 2003.

Rybicka E., Geopoetyka. Przestrzeń i miejsce we wspótczesnych teoriach i praktykach literackich, Kraków 2014. 
Sokolski J., "Jan Kochanowski," in: Historia literatury polskiej w dziesięciu tomach, t. 2, Renesans, red. A. Skoczek, Bochnia 2002, pp. 273-310.

Szczerbicka-Ślęk L., "Wstęp," in: J. Kochanowski, Pieśni, red. L. Szczerbicka-Ślęk, Wrocław 2008, pp. I-LXXIX.

Talbert R. J. A., Rome's World: The Peutinger Map Reconsidered, Cambridge 2010.

Tarnowski S., Studia do historyi literatury polskiej. Wiek XVI. Jan Kochanowski, Kraków 1888.

Tazbir J., "Szlachta a konkwistadorzy. Opinia staropolska wobec podboju Ameryki przez Hiszpanię," in: J. Tazbir, Prace wybrane, t. 3, Sarmaci i świat, Kraków 2001, pp. 7-313.

Thrower N. J. W., Maps and Civilization. Cartography in Culture and Society, Chicago-London 1996.

Ulewicz T., "Świadomość słowiańska Jana Kochanowskiego. Z zagadnień psychiki polskiego Renesansu," in: T. Ulewicz, Świadomość stowianska Jana Kochanowskiego. Europejskie oddziaływanie Jana Kochanowskiego, Kraków 2006, pp. 9-164.

Ulewicz T., Sarmacja. Studium z problematyki słowiańskiej XV i XVI w., Kraków 1950.

Unger R. W., Ships on Maps. Pictures of Power in Renaissance Europe, New York 2010.

Wilczek P., "Pieśni," in: Lektury polonistyczne. Jan Kochanowski, red. A. Gorzkowski, Kraków 2001, pp. 306-321.

Windakiewicz S., Jan Kochanowski, Warszawa 1947.

Wood D., Rethinking the Power of Maps, New York-London 2010.

Woodward D., "Cartography and the Renaissance: Continuity and change," in: The History of Cartography, vol. 3, Cartography in the European Renaissance, p. 1, ed. by D. Woodward, Chicago-London 2007, pp. 3-24.

Ziomek J., "Niezwykłe i nie leda pióro," in: Jan Kochanowski. Interpretacje, red. J. Błoński, Kraków 1989, pp. 95-107.

Ziomek J., Renesans, Warszawa 1977. 

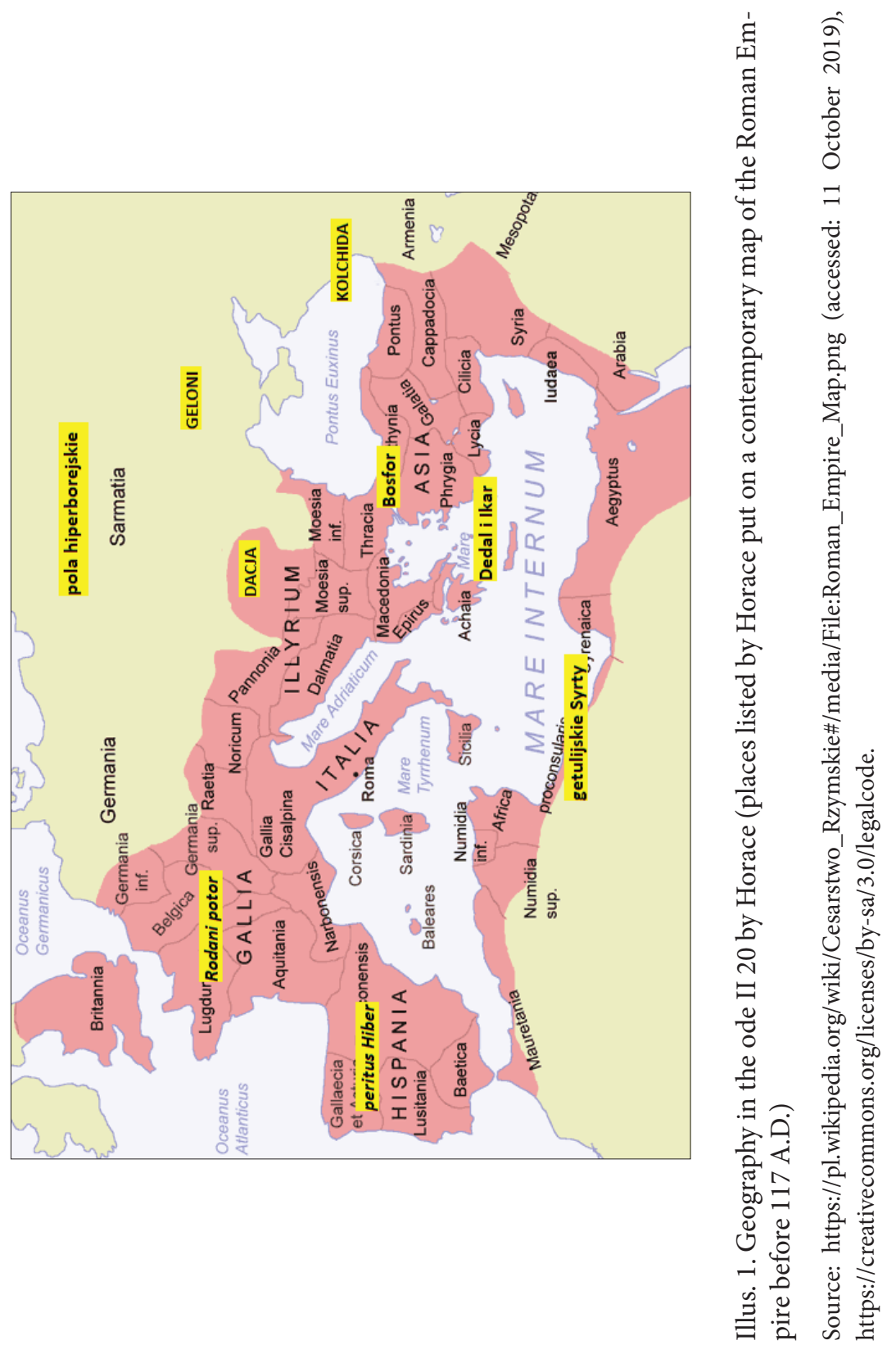

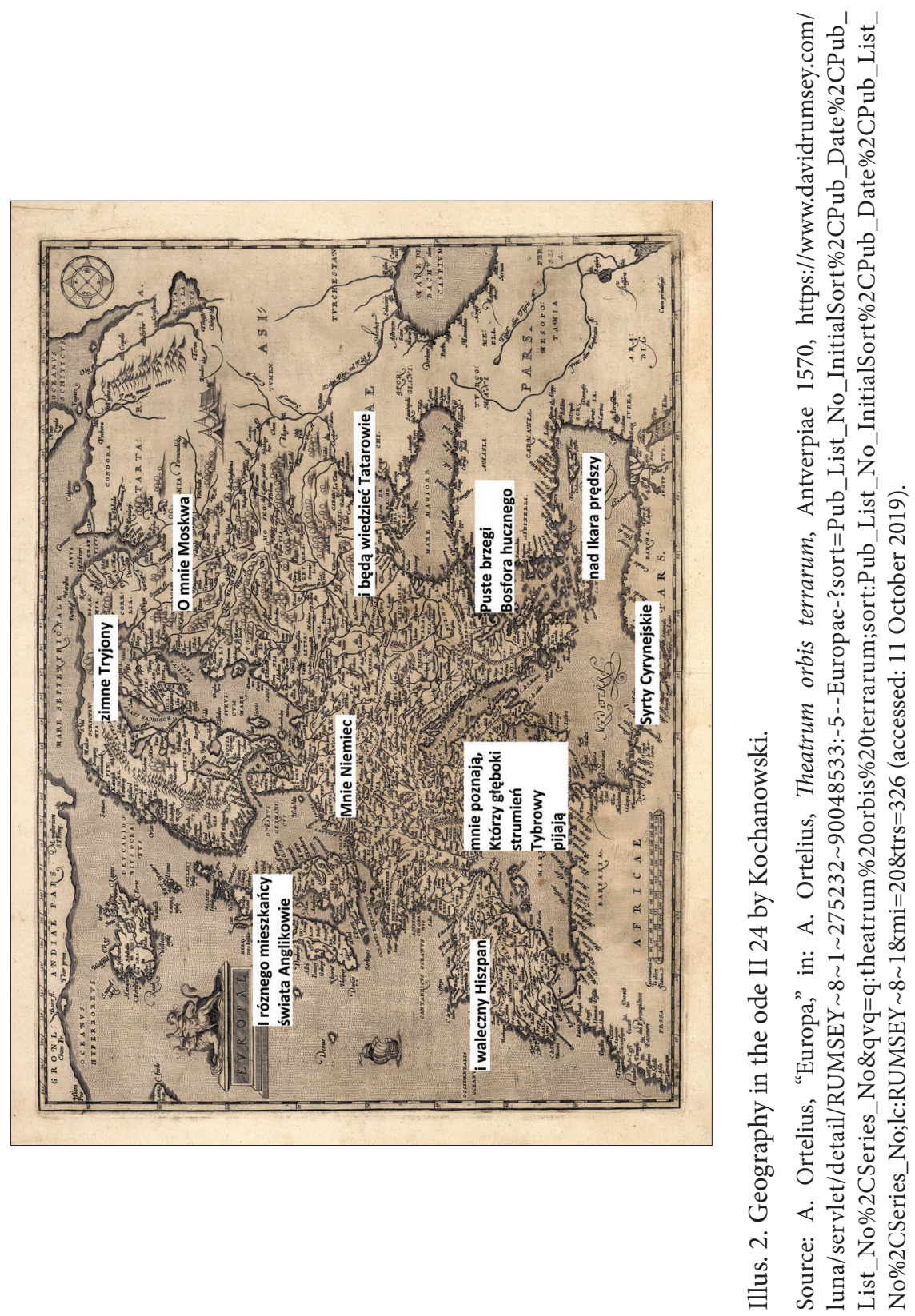


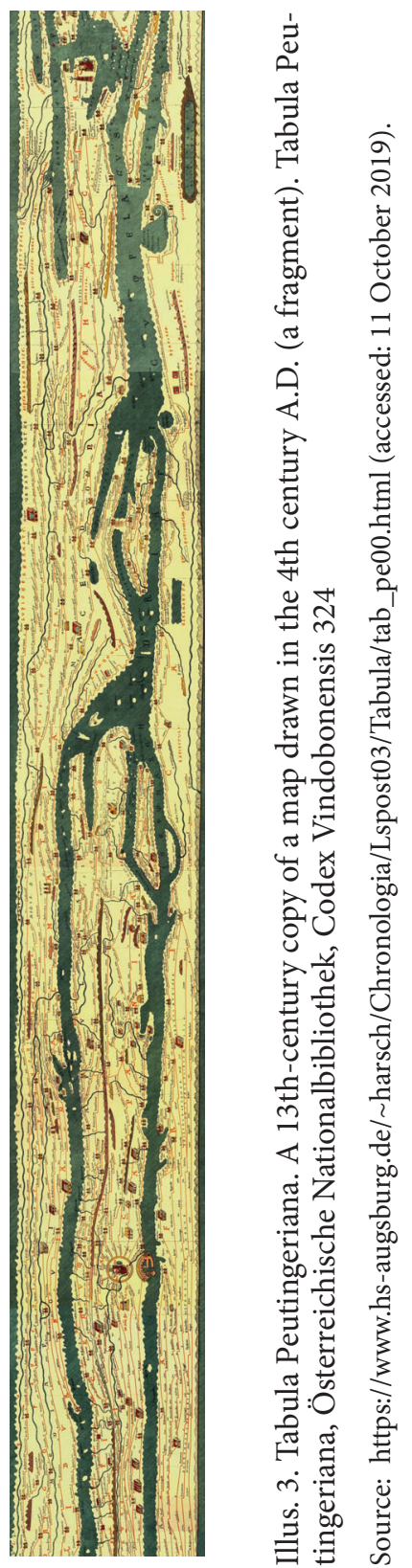

